\title{
PENGARUH PELATIHAN DAN PENGEMBANGAN SUMBER DAYA MANUSIA TERHADAP PRESTASI KERJA KARYAWAN PT.JEMBO ENERGINDO
}

\author{
Sugandha S.E., M.M. \\ Fx.Pudjo Wibowo S.E., M.M. \\ Hendra, SE., MM \\ Program Studi Manajemen, Universitas Buddhi Dharma, Banten \\ sugandhathe@gmail.com, fxpudjowibowo87@gmail.com
}

\begin{abstract}
ABSTRAK
Tujuan dari penulisan ini adalah untuk mengetahui pelatihan dan pengembangan sumber daya manusia terhadap prestasi kerja karyawan PT Jembo Energindo. Penelitian dilakukan dengan menyebar kuensioner, sedang metode penelitian dengan menggunakan Simple Random Sampling. Uji t hitung didapat nilai $\mathrm{t}$ hitungpelatihan $14.053>\mathrm{t}_{\text {tabel }} 1.65993$ dan $.000<0.05$ dan nilai $t$ hitungpengembangan sumber daya manusia $14.053>t_{\text {tabel }} 1.65993$ dan $.000<0.05$ sehingga hipotesis yang menyatakan pelatihan dan pengembangan sumber daya manusia berpengaruh positif secara parsial terhadap Prestasi Kerja Karyawan pada PT. Jembo Energindo.Uji $\mathrm{F}$, didapat $\mathrm{F}_{\text {hitung }}>\mathrm{F}_{\text {tabel }}$ atau $268.793>3.09$ atau tingkat signifikasi (sig) $0.000<0.05$ sehingga hipotesis yang menyatakan pelatihan dan pengembangan sumber daya manusia secara bersama-sama berpengaruh terhadap prestasi kerja karyawan pada PT. Jembo Energindo danSquare $\left(\mathrm{R}^{2}\right)$ koefisien determinasi menunjukkankoefisien determinasi yang berarti persentase kontribusi variabel independen, bahwa pelatihan dan pengembangan sumber daya manusia memberikan sumbangan sebesar 84,2\% terhadap Prestasi Kerja Karyawan pada PT. Jembo Energindo.
\end{abstract}

Kata Kunci: pelatihan, pengembangan sumber daya manusia dan prestasi kerja karyawan.

\section{ABSTRACT}

The purpose of this paper is to find out the training and development of human resources on the work performance of employees of PT Jembo Energindo. The study was conducted by spreading the questionnaire, while the research method used Simple Random Sampling. The t-test is obtained by the value of the training $t$ count of 14,053> ttable 1.65993 and $.000<0.05$ and the $t$ value of the calculation of human resource development is 14,053> ttable 1.65993 and $.000<0.05$ so that the hypothesis that training and development of human resources partially has a positive effect on achievement Employee Work at PT. Jembo Energindo. F test, obtained F count $>$ F table or 268,793> 3.09 or significance level ( $\operatorname{sig}) 0.000<0.05$ so that the hypothesis which states that training and development of human resources jointly influence the work performance of employees at PT. Jembo Energindo and Square (R2) coefficient of determination shows the coefficient of determination which means the percentage contribution of independent variables, that training and development of human resources contribute $84.2 \%$ to Employee Performance at PT. Jembo Energindo.

Keywords: training, human resource development and employee performance. 


\section{PENDAHULUAN}

Asset terpenting perusahaan yaitu mempunyai sumber daya manusia yang berperan aktif dan menguntungkan bagi perusahaan. Pengelolaan sumber daya manusia yang benar akan menimbulkan pencapaian tujuan. Setiap tahun perusahaan membuat sasaran dan tujuan supaya mendapatkan strategi yang cocok untuk memajukan usahanya. Tenaga kerja yang berkualitas menjadikan suatu keuntungan bagi perusahaan karena sebuah proses untuk mencapai suatu tujuan organisasi dengan bekerja secara bersama-sama.

PT Jembo Energindo merupakan salah satu perusahaan yang mengandalkan sumber daya manusianya. Untuk meningkatkan kualitas sumber daya manusia yang baik maka diperlukan pelatihan yang berkualitas. Meskipun dalam pelatihan sumber daya manusia memerlukan biaya yang tidak sedikit, tetapi program pelatihan harus tetap berjalan karena mempunyai manfaat yang begitu besar untuk karyawan itu sendiri maupun perusahaan.

Pengembangan karyawan penting bagi setiap individu karyawan. Karyawan yang bekerja tentunya mengharapkan adanya perkembangan yang positif. Pengembangan karyawan ini mempunyai cakupan yang luas dan berfokus pada individu karyawan. Efisiensi organisasi sangat tergantung dari baik buruknya pengembangan individu karyawan itu sendiri . Banyaknya tujuan pengembangan sumber daya manusia maka adanya peran perusahaan yang mengharapkan seorang karyawan berkembang karena tuntutan pekerjaan saat ini atau masa yang akan datang. Oleh karena itu pengembangan sumber daya manusia merupakan realisasi hubungan antara kesadaran dan pemahaman dengan organisasi.

Tujuan utama dari pengembangan sumber daya manusia adalah untuk meningkatkan kualitas karyawan itu sendiri dan upaya untuk meningkatkan prestasi kerja karyawan dimana perusahaan dapat bertahan pada persaingan industri yang semakin tinggi dan kompleks. Karyawan yang mempunyai keinginan yang kuat akan berpengaruh pada pengetahuan kemampuan, keterampilan dan kualitas kerja. Menyadari hal ini, pengembangan adalah proses yang bejalan secara terusmenerus dan tidak hanya sesaat saja. Masalah baru yang timbul, pengetahuan serta jabatan baru selalu ada di dalam organisasi yang dinamis dan tantangan bagi manajemen untuk menempatkan karyawan yang profesional yang baik untuk mencapai tujuan dan target yang telah dibuat manajemen.

Prestasi kerja karyawan dipengaruhi oleh bermacam-macam ciri pribadi dan masing-masing individu. Prestasi kerja karyawan yang memperlihatkan peningkatannya akan mendapatkan penilaian yang baik dan sebagai hasil dari perilaku kerja karyawan yang berkaitan dengan melaksanakan tugas dan tanggung jawabnya.

\section{Perumusan Masalah :}

1. Seberapa besar pengaruh masingmasing variabel pelatihan dan pengembangan sumber daya manusia terhadap prestasi kerja karyawan pada PT Jembo Energindo?

2. Seberapa besar pengaruh scara bersama-sama variabel variabel pelatihan dan pengembangan sumber daya manusia terhadap prestasi kerja karyawan pada PT Jembo Energindo?

\section{Tujuan Penelitian :}

1. Untuk menguji pengaruh pelatihan terhadap prestasi kerja karyawan pada PT Jembo Energindo. 
2. Untuk menguji pengaruh pengembangan sumber daya manusia terhadap prestasi kerja karyawan pada PT Jembo Energindo.

3. Untuk menguji pelatihan dan pengembangan sumber daya manusia terhadap prestasi kerja karyawan pada PT Jembo Energindo

\section{Manfaat Penelitian}

1. Bagi Perusahaan, penelitian ini berguna untuk mengetahui variabelvariabel yang mempengaruhi dan paling berpengaruh terhadap prestasi kerja karyawan, sehingga dapat menjadi beban pertimbangan untuk memperoleh informasi yang lebih baik dalam usaha membangun guna mencegah persoalan pelatihan dan pengembanganh sumber daya manusia yang dihadapi karyawan sehingga dapat meningkatkan prestasi kerja karyawan.

2. Bagi peneliti dapat dijadikan sarana informasi untuk meningkatkan wawasan dan pengetahuan tentang cara mengukur pelatihan dan pengembangan sumber daya manusia dan factor dominan dalam meningkatkan prestasi kerja karyawan.

3. Bagi akademis dan pembaca yang lain, dapat digunakan untuk pengembangan ilmu pengetahuan, menambah wawasan dan informasi gambaran bagaimana cara mengukur tingkat prestasi kerja karyawan dalam rangka peningkatan produktivitas karyawan suatu perusahaan.

\section{LANDASAN TEORI}

Pelatih mempunyai peranan yang sangat penting terhadap kemajuan kemampuan para karyawan yang akan dikembangkan. Hampir semua karyawan baru memerlukan pelatihan agar dapat melakukan pekerjaannya dengan baik. Menurut Gary Dessler (2015: 284) pada buku Manajemen Sumber Daya Manusia menyatakan bahwa :"Pelatihan berarti memberikan kepada karyawan baru atau karyawan yang ada keterampilan yang mereka butuhkan untuk melakukan pekerjaan mereka, seperti memperlihatkan kepada tenaga penjual baru mengenai cara menjual produk anda"

Menurut Mutiara Simbarani Panggabean (2016:4) dalam bukunya yang berjudul Manajemen Sumber Daya Manusia menyatakan bahwa:Pelatihan dapat didefinisikan sebagai suatu cara yang digunakan untuk mempelajari keterampilan yang dibutuhkan karyawan baru untuk melaksanakan pekerjaannya sekarang, bahkan pembelajaran yang berkesinambungan yang bermanfaat guna mendukung strategi bisnis dan memperoleh keunggulan bersaing".

\section{Pengembangan}

Pengembangan dimana berkaitan dengan menunjukan tumbuh dan berkembang dari karyawan dimana perkembangan tersebut timbul dari keinginan karyawan tersebut dan akan selalu memperbaiki kapasitasnya untuk menjadi lebih baik supaya tujuannya dapat tercapai.

Menurut Mutiara Sibarani Panggabean (2016:50) pada buku Manajemen Sumber Daya Manusia menyatakan bahwa: "Pengembangan karyawan berorientasi kepada masa depan dan lebih peduli terhadap pendidikan, yaitu terhadap peningkatan kemampuan seseorang untuk memahami dan menginterprestasi pengetahuan, bukanmengajarkan keterampilan teknis".

MenurutSedarmayanti (2017:119) dalambuku Perencanaan dan Pengembangan Sumber Daya Manusia menyatakanbahwa :

"Pengembangan merupakan kesempatan belajar untuk membantu individu/pegawai dapat berkembang dalam jangka panjang.Pengembangan dapat berupa pendidikan formal, 
pengalamankerja, hubungan interpersonal ataupenilaian personality, sertakemampuanuntuk membantu pegawai mempersiapkan masa depan".

\section{Prestasi Kerja}

Prestasikerjasangatberkaitandenganpe gawaidenganprestasikerja yang bagus dan hasil kerja yang baik.

MenurutSamsudin

(dalamEdySuryanto, Leonardo Budi Hasiolan, Aziz Fathoni, 2015) padabukuPengaruhKepuasanKerja Dan Disiplin Kerja Terhadap PrestasiKerja Karyawan, menyatakan bahwaPrestasi kerja adalah kemampuan seseorang untuk menyelesaikan pekerjaan yang diberikan kepadanya dengan kesungguhan dan ketepatan waktu serta pengalaman yang ia miliki sehingga dapat menghasilkan sesuatu yang positif yang dapat menentukan perkembangan kariernya di masa yang akan datang

\section{Kerangka Pemikiran Konseptual}

Kerangka konseptual tersebut dijelaskan pada kerangka pikir berikut :

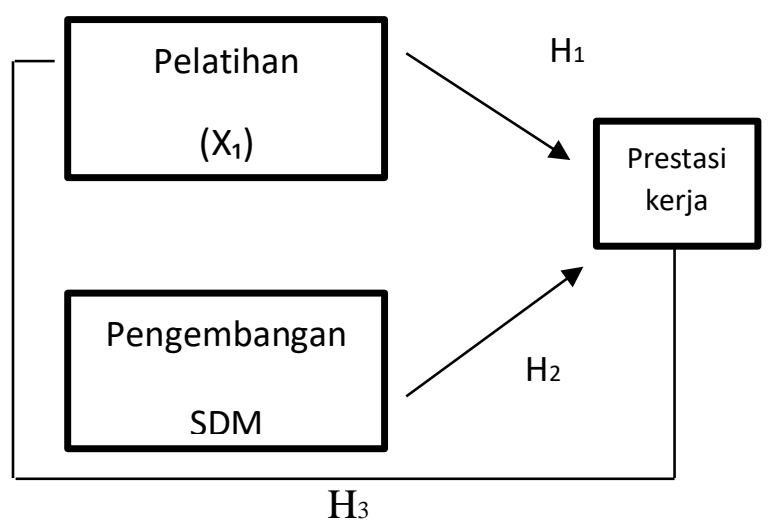

\section{Hipotesis}

Hipotesa ini masih merupakan dugaan sementara dan masih perlu diuji

kebenarannya.

$\mathrm{H}_{1}$ :Diduga pelatihan mempunyai pengaruh yang signifikan terhadap prestasi kerja karyawan PT Jembo Energindo.

$\mathrm{H}_{2}$ :Diduga pengembangan sumber daya manusia mempunyai pengaruh yang signifikan terhadap prestasi kerja karyawan PT Jembo Energindo

$\mathrm{H}_{3}$ :Diduga pelatihan dan pengembangan sumber daya manusia mempunyai pengaruh yang signifikan terhadap prestasi kerja karyawan PT Jembo Energindo

\section{METODE PENELITIAN}

\section{Variabel Penelitian dan Definisi}

\section{Operasional Variabel}

Dalam penelitian ini variable bebas/independen adalah pelatihan $\left(\mathrm{X}_{1}\right)$, dan pengembangan sumber daya manusia $\left(\mathrm{X}_{2}\right) \quad$ sedangkan variabel terikat/dependen adalah prestasi kerja karyawan (Y) 


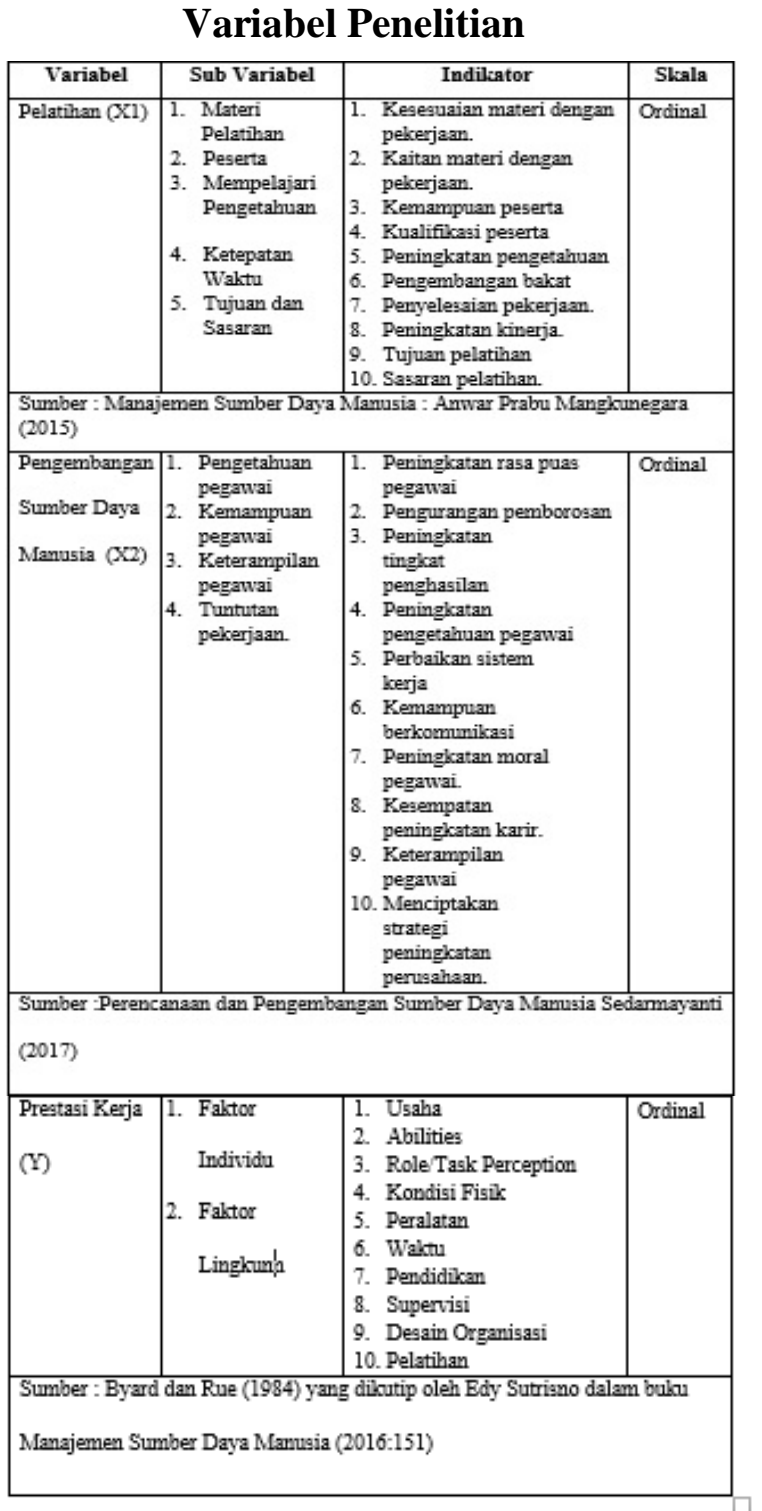

Populasi dan sampel dan Teknik

\section{Pengambilan Sampel}

\section{Lokasi Penelitian : PT Jembo Energindo}

\section{Pengukuran Variabel}

Semua variabel yang digunakan dalam penelitian digunakan skala Likert (rentang nilai 1 sampai dengan 5) di mana jawaban responden di beri nilai sebagai berikut sangat setuju (SS) skor 5, setuju (S) skor 4 ragu-ragu skor 3, tidak setuju skor 2 dan sangat tidak setuju skor 1

\section{Populasi dan Sampel}

Populasi

Menurut Sugiyono (2011 : 80) dalam bukunya yang berjudul Metode Penelitian Kuantitatif Kualitatif dan R\&D menyatakan bahwa "Populasi diartikan sebagai wilayah generalisasi yang terdiri atas objek-objek yang mempunyai kualitas dan karakteristik tertentu yang ditetapkan oleh peneliti untuk dipelajari dan kemudian ditarik kesimpulannya".

Populasi dalam penelitian ini adalah seluruh karyawan PT. Jembo Energindo.

\section{Sampel}

Menurut Sugiyono (2011 : 80) dalam bukunya yang berjudul Metode Penelitian Kuantitatif Kualitatif dan R\&D menyatakan bahwa "Sampel adalah bagian dari jumlah dan karakteristik yang dimiliki oleh populasi tersebut". Besarnya populasi dalam penelitian yang akan dilakukan, dan waktu terbatas yang dimiliki oleh peneliti, maka sampel yang diambil adalah sebanyak 104 orang. Sampel diambil secaraSimple Random Samplingkarena pengambilan anggota sampel dari populasi digunakan sebagai sampel tanpa memperhatikan strata yang ada dalam populasi itu.

\section{Pengujian Instrumen Penelitian}

\section{Uji Validitas Dan Realibilitas}

\section{Uji Validitas}

Uji validitas merupakan uji isntrumen data untuk mengetahui seberapa cermat suatu item dalam mengukur apa yang ingin diukur. Item dapat dikatakan valid jika adanya korelasi yang signifikan dengan skor totalnya, hal ini menunjukan adanya dukungan item tersebut dalam mengungkap suatu yang ingin diungkap. Item tersebut dapat berupa pertanyaan yang ditunjukan kepada responden 
dengan menggunakan kuisioner dengan tujuan untuk mengungkap sesuatu. Dalam pengujian ini metode analisis yang digunakan dalam uji validitas item adalah metode korelasi pearson. Teknik uji validitas dengan metode korelasi pearson yaitu dengan cara mengorelasikan skor item dengan skor totalnya. Skor total adalah penjumlahan seluruh item pada satu variabel. Adapun kriteria signifikasi pada pengujian ini adalah dengan menggunakan tingkat signifikasi, jika signifikasi $\leq 0,05$ maka item valid, tetapi jika signifikasi $\geq 0,05$ maka item tidak valid.

\section{Uji Reliabilitas}

Uji reliabilitas (reliability) merupakan kelanjutan dari uji validitas, dimana item yang masuk pengujian adalah item yang valid saja. Uji ini digunakan untuk mengetahui konsistensi alat ukur yang digunakan menggunakan kuisioner. Metode yang sering digunakan dalam penelitian adalah metode Cronbach Alpha. Adapun kriteria dalam pengujian reliabilitas adalah reliabilitas kurang dari 0,6 adalah kurang baik, sedangkan 0,7 dapat diterima dan diatas 0,8 adalah baik atau dinyatakan reliabel.

\section{Pengujian Asumsi Klasik}

\section{Uji Normalitas}

Bertujuan untuk menguji apakah dalam model regresi, variabel pengganggu atau Uji Heterokesdatisitas

Uji Heterokesdatisitas digunakan untuk menguji apakah dalam sebuah regresi terdapat kesamaan varians dari residu dari satu pengamatan ke pengamatan yang lain sama. Cara mendeteksi heterokesdatisitas dalam penelitian ini dengan melihat pola sebaran grafik scatter plot. Jika ada pola tertentu, seperti titik yang ada berbentuk suatu pola tertentu yang teratur (bergelombang, melebar, kemudian menyempit ) maka telah terjadi heteroskedestisitas. residual memiliki distribusi normal. Penelitian ini menggunakan plot probabilitas normal (Normal probability plot) untuk menguji kenormalitasan jika penyebaran data (titik) disekitar sumbu diagonal dan mengikuti arah garis diagonal, maka model regresi memenuhi asumsi Normalitas.

\section{Uji Multikolinearitas}

Uji multikoniearitas bertujuan untuk menguji apakah model regresi ditemukan adanya korelasi antar variabel bebas (independen). Dalam model regresi yang baik seharusnya tidak terjadi korelasi diantara variabel bebas. Uji Multikolineritas dilakukan dengan melihat Tolerance dan Variance Inflasion Factor (VIF). Apabila nilai tolerance< 0.10 atau sama dengan nilai VIF > 10. (Ghozali, 2010:91).

\section{Uji Autokorelasi}

Ada atau tidaknya autokorelasi ini dapat dilakukan dengan menggunakan uji statistic Durbin - Watson. Adapun dasar pengambilan keputusan dalam uji Durbin - Watson (Santoso, 2005), sebagai berikut, bila angka Durbin - Watson berada di bawah -2, berarti autokorelasi, bila angka Durbin - Watson diantara -2 sampai +2, berarti tidak ada autokorelasi.dan bila angka Durbin Watson di atas +2 , berarti ada autokorelasi negative.

\section{Metode Regesi Berganda}

Metode regresi berganda merupakan studi mengenai keterangan variabel dependen dengan salah satu atau lebih variabel idenpenden, dengan tujuan untuk mengestimasi rata-rata populasi atau nilai rata-rata varibel dependen berdasarkan nilai variabel independen yang diketahui. Data pengamatan biasanya tidak hanya disebabkkan oleh suatu variabel, melainkan oelh beberapa atau bahkan banyak variabel. Untuk itu peneliti menggunakan regresi linear berganda 
untuk menganalisis hubungan dan pengaruh suatu variabel terkait dengan dua atau lebih variabel bebas dengan rumus sebagai berikut :

$\mathrm{Y}=\mathrm{a}+\mathrm{b}_{1} \mathrm{X}_{1}+\mathrm{b}_{2} \mathrm{X}_{2}$

Dimana :

Y : prestasi kerja karyawan

$\mathrm{X}_{1}$ : pelatihan

$\mathrm{X}_{2}$ : pengembangan sumber daya manusia

a : Nilai konstan

$\mathrm{b}_{1}, \mathrm{~b}_{2}$ : Koefisien regresi

\section{Koefisien Determinasi $\left(\mathbf{R}^{\mathbf{2}}\right)$}

Koefisien Determinasi $\left(\mathrm{R}^{2}\right)$ menunjukkan seberapa besar kemampuan independent (pelatihan dan pengembangan sumber daya manusia) menjelaskan variabel dependent (prestasi kerja karyawan)

\section{Uji t}

Uji $t$ bertujuan untuk mengetahui besarnya pengaruh masing-masing variabel bebas secara parsial/individu terhadap variabel terikatnya (V. Wiratna Sujarweni 2015)variabel bebas berpengaruh secara parsial terhadap variabel terikat secara signifikan bila nilai $t_{\text {hitung }}>t_{\text {tabel }}$

Uji F

Uji F digunakan untuk menguji apakah variabel bebas dalam penelitian ini mempunyai pengaruh secara simultan/bersama-sama terhadap variabel terikat dengan membandingkan nilaiF hitung $>$ nilai $\mathrm{F}_{\text {tabel }}$

\section{ANALISIS DAN PEMBAHASAN}

Pada penelitian ini penulis mengambil beberapa orang atau responden untuk dijadikan sampel dalam menjawab pernyataan-pernyataan yang diajukan penulis mengenai analisis pengaruh pelatihan dan pengembangan sumber daya manusia terhadap prestasi kerja karyawanPT Jembo Energindo dalam bentuk beberapa pernyataan atau kuesioner yang diajukan kepada 104 orang atau responden.

\section{Uji Validitas dan Uji Realibilitas}

\section{Uji Validitas}

Pengujian validitas tiap butir pertanyaan dalam penelitian ini dilakukan dengan mengkorelasikan skor tiap butir dengan skor total.Dengan membandingkan nilai $r$ hitung dengan $r$ tabel. Jika $\mathrm{r}$ hitung $>\mathrm{r}$ tabe ımaka indikator dinyatakan valid.

Tabel 1. Uji Validitas pelatihan dan pengembangan sumber daya manusia, dan prestasi kerja Karyawan

\begin{tabular}{|c|c|c|c|}
\hline $\begin{array}{c}\text { Butir } \\
\text { Pertanyaan }\end{array}$ & $\mathbf{r}_{\text {able }}$ & $\mathrm{r}$ litunisit & Keterangan \\
\hline $\mathrm{X}_{1.1}$ & 0,1927 &, 703 & Valid \\
\hline $\mathrm{X}_{1} .2$ & 0,1927 & .394 & Valid \\
\hline $\mathrm{X}_{1} .3$ & 0,1927 & .443 & Valid \\
\hline $\mathrm{X}_{1} .4$ & 0,1927 & ,610 & Valid \\
\hline $\mathrm{X}_{1.5}$ & 0,1927 &, 617 & Valid \\
\hline $\mathrm{X}_{1} .6$ & 0,1927 & 664 & Valid \\
\hline $\mathrm{X}_{1 .} .7$ & 0,1927 & .611 & Valid \\
\hline $\mathrm{X}_{1}, 8$ & 0,1927 & .544 & Valid \\
\hline $\mathrm{X}_{1} .9$ & 0,1927 & .433 & Valid \\
\hline $\mathrm{X}_{1.10}$ & 0,1927 & .463 & Valid \\
\hline $\mathrm{X}_{2} .1$ & 0,1927 &, 533 & Valid \\
\hline $\mathrm{X}_{2} \cdot 2$ & 0,1927 & 604 & Valid \\
\hline $\mathrm{X}_{2.3}$ & 0,1927 &, 430 & Valid \\
\hline $\mathrm{X}_{2} .4$ & 0,1927 & .389 & Valid \\
\hline $\mathrm{X}_{2} .5$ & 0,1927 & .447 & Valid \\
\hline $\mathrm{X}_{2} .6$ & 0,1927 & , 309 & Valid \\
\hline $\mathrm{X}_{2.7}$ & 0,1927 & 604 & Valid \\
\hline $\mathrm{X}_{2}, 8$ & 0,1927 & .576 & Valid \\
\hline $\mathrm{X}_{2} .9$ & 0,1927 &, 462 & Valid \\
\hline $\mathrm{X}_{2.10}$ & 0,1927 & 652 & Valid \\
\hline Y.1 & 0,1927 & 322 & Valid \\
\hline $\mathrm{Y} .2$ & 0,1927 &, 573 & Valid \\
\hline Y.3 & 0,1927 & .550 & Valid \\
\hline Y.4 & 0,1927 &, 587 & Valid \\
\hline Y.5 & 0,1927 & 657 & Valid \\
\hline Y.6 & 0,1927 & .760 & Valid \\
\hline Y.7 & 0,1927 & .747 & Valid \\
\hline $\mathrm{Y}, 8$ & 0,1927 & .499 & Valid \\
\hline Y.9 & 0,1927 & .749 & Valid \\
\hline Y.10 & 0,1927 & ,548 & Valid \\
\hline
\end{tabular}


Tabel 1. menunjukkan bahwa setiap item pertanyaan pelatihan, pengembangan sumber daya manusia, dan prestasi kerja karyawan semuanya valid karena nilai $r$ hitung $>r_{\text {tabel }}$

\section{Uji Realibilitas}

Uji realibilitas dilakukan untuk menilai konsistensi dari instrument penelitian. Instrument dapat dikatakan realibel jika nilai Cronbach's Alpha $>$ nilai $\alpha=0,70$.

Tabel 2. Hasil Uji Reliabilitas

\begin{tabular}{|l|l|l|}
\hline Variabel & $\begin{array}{c}\text { Cronbach' } \\
\text { s Alpha }\end{array}$ & $\begin{array}{c}\text { Keteranga } \\
\mathrm{n}\end{array}$ \\
\hline Pelatihan & 0.846 & Reliabel \\
\hline $\begin{array}{l}\text { Pengembanga } \\
\text { n Sumber } \\
\text { Daya Manusia }\end{array}$ & .0 .817 & Reliabel \\
\hline $\begin{array}{l}\text { Prestasi kerja } \\
\text { karyawan }\end{array}$ & 0.874 & Reliabel \\
\hline
\end{tabular}

Sumber : Data diolah

Tabel 2 menunjukkan bahwa semua pernyataan yang digunakan dalam variabel ini adalah reliabel.

\section{Pengujian Uji Asumsi Klasik}

\section{a. Hasil Uji Normalitas Data}

Uji Normalitas data adalah merupakan gambal visual yang menunjukkan jauh dekatnya titik-titik pada gambar tersebut dengan garis diagonal, jika data yang berasal dari distribusi normal, maka nilai-nilai sebaran data yang tercermin dalam titik-titik pada ouput akan terletak di sekitar garis diagonal, sebaliknya jika data berasal dari distribusi yang tidak normal maka titik-titik tersebut tersebar tidak di sekitar garis diagonal (terpencar jauh dari garis diagonal (terpencar jauh dari garis diagonal)

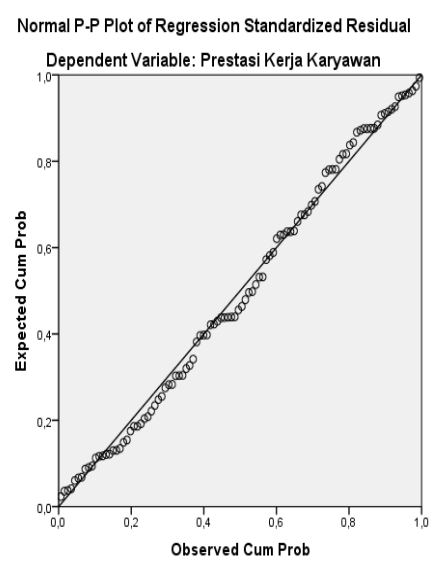

Gambar 1. Hasil Uji Normalitas Menggunakan Grafik P.Plot

Gambar 1 menunjukkan bahwa data tersebar di sekeliling garis diagonal dan tidak terpencar jauh dari garis diagonal, dan melihat titik-titik yang mengikuti arah garis linier dari kiri ke bawah ke kanan atas. Dan dapat disimpulkan bahwa model dalam penelitian ini memenuhi persayaratan normalitas data.

b. Hasil Uji Multikolinerieritas

Suatu model regresi dikatakan dari masalah multikolinearitas dengan Cara mengetahui ada atau tidaknya gejala multikolinieraritas antara lain dengan melihat nilai variance inflation factor (VIF) dan tolerance, apabila nilai VIF kurang dari 10 dan Tolerance lebih dari 0,1 maka dinyatakan tidak terjadi multikoliniearitas.

Tabel 3. Uji Multikolineritas

\begin{tabular}{|l|r|c|c|}
\hline \multicolumn{1}{|c|}{ Variabel } & Tolerance & VIF & Keterangan \\
\hline Pelatihan (X1) & .475 & 2.104 & Tidak terjadi Multikolinearitas \\
\hline $\begin{array}{l}\text { Pengembangan Sumber } \\
\text { Daya Manusia (X2) }\end{array}$ & .475 & 2.104 & Tidak terjadi Multikolinearitas \\
\hline
\end{tabular}

Tabel 3 menunjukkan bahwa variabel pelatihan (X1) dan pengembangan sumber daya manusia (X2) tidak terjadi multikoliniearitas karena nilai VIF kurang dari 10 dan Tolerance lebih dari 0,1 


\section{c. Hasil Uji Autokorelasi}

Ada atau tidaknya autokorelasi ini dapat dilakukan dengan menggunakan uji statistic Durbin - Watson. Adapun dasar pengambilan keputusan dalam uji Durbin - Watson (Santoso, 2005), sebagai berikut, bila angka Durbin Watson berada di bawah -2, berarti autokorelasi, bila angka Durbin Watson diantara -2 sampai +2 , berarti tidak ada autokorelasi.

dan bila angka Durbin - Watson di atas +2 , berarti ada autokorelasi negatif, dari perhitungan hasil output SPSS persamaan regresi dalam penelitian ini dimana D-W (DurbinWatson), sebesar 2.161, untuk nilai dL adalah 1.3908 dan nilai dU adalah 1.6000, maka nilai $4-\mathrm{dU}=2,4000$ dan $4-\mathrm{dL}=$ 2.6092, hal dapat disimpulkan berarti model regresi diatas tidak terdapat masalah autokorelasi.

\section{d. Uji Heteroskedastisitas}

Dasar pengambilan keputusan dalamanalisis heteroskedastisitas adalahsebagai berikut (Santoso, 2005), Jika ada pola tertentu, seperti titiktitikyang ada membentuk pola tertentu yang teratur (bergelombang, melebar kemudian menyempit), maka sudah menunjukkan telah terjadinya gejala heteroskedastisitas dan Jika tidak ada pola yang jelas, serta titiktitik menyebar diatas dan di bawah angka 0 pada sumbu Y, makatidak terjadi heteroskedastisitas.

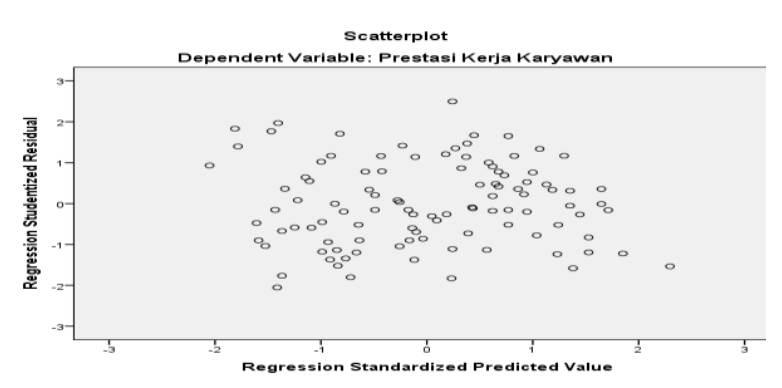

Scatterplot
Gambar 2 menunjukkan bahwa titik-titik yang dihasilkan menyebar secara acak dan tidak membentuk pola atau trend garis tertentu dan data tersebut tersebar diatas dan dibawah angka 0 sehingga model regresi layak digunakan untuk memprediksi prestasi kerja karyawan berdasarkan variabel yang mempengaruhi yaitu pelatihan dan pengembangan sumber daya manusia

\section{Analisis Linier Berganda}

Untuk mengetahui ada tidaknya hubungan antara variabel $\mathrm{X}_{1}$ (pelatihan), variabel $\mathrm{X}_{2}$ (pengembangan SDM ), terhadap Y (prestasi kerja karyawan), serta mengukur kuat tidaknya hubungan

serta mengukur kuat tidaknya hubungan tersebut, maka digunakan analisa regresi berganda dengan perhitungan SPSS (Statistical Package Service Softition), Versi 20.0,

Tabel 4.
\begin{tabular}{|l|r|r|r|}
\hline \multicolumn{1}{|c}{ Hasil Perhitungan Regresi Berganda } \\
\hline Variabel & $\begin{array}{c}\text { Koefisien } \\
\text { Regresi }\end{array}$ & T hitung & Sig \\
\hline Konstanta & 1,778 & 1,068 & .288 \\
\hline Pelatihan $\left(\mathrm{X}_{1}\right)$ &, 942 & 14,053 & .000 \\
\hline $\begin{array}{l}\text { Pengembangan Sumber Daya } \\
\text { Manusia }\left(\mathrm{X}_{2}\right)\end{array}$ &, 177 & 2,536 & .013 \\
\hline $\begin{array}{l}\text { F hitung }: 268.793 \\
\text { Sig }\end{array} 0.000$ & & & \\
\hline Adjusted R2 :0.839 & & & \\
\hline R :0.918 & & & \\
\hline
\end{tabular}

Sumber : Data diolah

Berdasarkan tabel 4 diatas dapat dibentuk persamaan regresi berganda :

$$
\mathrm{Y}=1.778+0,, 942 \mathrm{X}_{1}+0,, 177 \mathrm{X}_{2}+\ldots \beta
$$

Persamaan tersebut mempunyai arti sebagai berikut:

1. Nilai konstanta (a) positif 1.778 menunjukkan besarnya Prestasi Kerja Karyawan pada PT. Jembo Energindo, jika tidak ada variabel Pelatihan, Pengembangan SDM adalah positif 1.778 satuan. 
2. Nilai koefisien regresi $\left(b_{1}\right)$ variabel pelatihan positif sebesar 0.942 berarti terdapat pengaruh positif dari variabel pelatihan terhadap Prestasi Kerja Karyawan pada PT. Jembo Energindosebesar 0.942 dengan asumsi variabel lainnya tetap atau konstan.

3. Nilai koefisien regresi $\left(b_{2}\right)$ variabel pengembangan Sumber Daya Manusia positif sebesar 0.177 berarti terdapat pengaruh positif dari variabel pengembangan Sumber Daya Manusiaterhadap Prestasi Kerja Karyawan pada PT. Jembo Energindosebesar 0.672dengan asumsi variabel lainnya tetap atau konstan.

\section{Uji t}

Tabel 5. Uji t

\begin{tabular}{|c|c|c|c|c|c|c|}
\hline 田 & \multicolumn{6}{|c|}{ Tabel 5. Ujit } \\
\hline \multirow[t]{2}{*}{ Mode } & & \multicolumn{2}{|c|}{$\begin{array}{c}\text { Unstandardized } \\
\text { Coefficients }\end{array}$} & \multirow{2}{*}{$\begin{array}{c}\text { Standardized } \\
\text { Coefficients } \\
\text { Beta }\end{array}$} & \multirow[t]{2}{*}{$\mathrm{t}$} & \multirow[t]{2}{*}{ Sig. } \\
\hline & & B & $\begin{array}{l}\text { Std. } \\
\text { Error }\end{array}$ & & & \\
\hline \multirow{3}{*}{1} & (Constant) & 1.778 & 1,665 & & 1,068 & .288 \\
\hline & Pelatihan &, 942 & ,067 & 807 & 14,053 & ,000 \\
\hline & $\begin{array}{l}\text { Pengembangan Sumber Daya } \\
\text { Manusia }\end{array}$ &, 177 &, 070 & , 146 & 2,536 &, 013 \\
\hline
\end{tabular}

a. Dependent Variable: Prestasi Kerja Karyawan

\section{Sumber : Hasil Olahan SPSS 20}

Tabel 5 menunjukkan bahwa :

a. Variabel pelatihan secara parsial berpengaruh positif dan signifikan (nilai $\mathrm{t}$ hitungpelatihan $14.053>\mathrm{t}_{\text {tabel }} 1.65993$ dan $.000<0.05$ terhadap Prestasi Kerja Karyawan pada PT. Jembo Energindo.

b. Variabel Pengembangan Sumber daya Manusia secara parsial berpengaruh positif dan signifikan (nilai $t$ hitungpengembangan sumber daya manusia $2.536>\mathrm{t}_{\text {tabel }} 1.65993$ dan .013 < 0.05 terhadap Prestasi Kerja Karyawan pada PT. Jembo Energindo.

\section{Uji F}

Tabel 6. Tabel F

\begin{tabular}{|c|c|c|c|c|c|c|}
\hline \multicolumn{7}{|c|}{ ANOVA } \\
\hline Mod & & Sum of Squares & df & Mean Square & $\mathrm{F}$ & Siq. \\
\hline \multirow{3}{*}{1} & Regression & 4172,020 & 2 & 2086,010 & 268,793 &, $000^{b}$ \\
\hline & Residual & 783.826 & 101 & 7,761 & & \\
\hline & Total & 4955,846 & 103 & & & \\
\hline
\end{tabular}

a. Dependent Variable: Prestasi Kerja Karyawan

b. Predictors: (Constant), Pengembangan Sumber Daya Manusia, Pelatihan

Sumber : Hasil Olahan SPSS 20

Tabel 6 menunjukkan bahwa nilai $\mathrm{F}$ hitung sebesar 268.793 dengan nilai signifikansi sebesar 0.000 sehingga nilai $F$ hitung $>F$ tabel atau $268.793>3.09$ atau tingkat signifikasi (sig) $0.000<0.05$, maka dapat disimpulkan berpengaruh secara simultan (bersama-sama) antarapelatihan dan pengembangan sumber daya manusia, terhadap prestasi kerja karyawan pada PT. Jembo Energindo

\section{Uji R dan $\mathbf{R}^{\mathbf{2}}$}

Tabel $7 \mathrm{Uji} \mathrm{R}$ dan $\mathrm{R}^{2}$

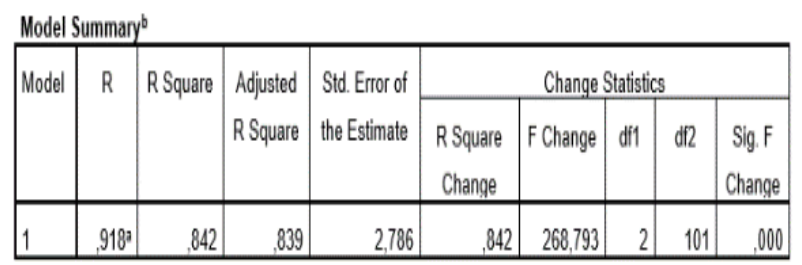

a. Predictors: (Constant), Pengembangan Sumber Daya Manusia, Pelatihan

b. Dependent Variable: Prestasi Kerja Karyawan Sumber: Hasil Olahan SPSS 20

Dari tabel 7 menunjukkan bahwa : 
1. Kolom $\mathrm{R}$ menunjukkan angka koefisien korelasi sebesar 0,918. Hal ini berarti pengaruh antara pelatihan dan pengembangan sumber daya manusia dengan prestasi kerja karyawan adalah cukup kuat.

2. Kolom R Square sebesar $0,842 \mathrm{Hal}$ ini menunjukkan besarnya pengaruh pelatihan dan pengembangan sumber daya manusia terhadap prestasi kerja karyawan adalah $84,2 \%$, sedangkan sisanya $(100 \%-84,2 \%=13,8 \%)$ dipengaruhi oleh faktor-faktor lain. $\mathrm{R}$ Square berkisar pada 0 sampai 1, semakin besar $\mathrm{R}$ Square maka semakin kuat hubungan antara pelatihan dan pengembangan sumber daya manusia dengan prestasi kerja karyawan atau sebaliknya.

\section{KESIMPULAN DAN SARAN}

Berdasarkan penelitian studi empiris yang dilakukan mengenai analisis pelatihan dan pengembangan sumber daya manusia, hasil yang diperoleh dengan menggunakan regresi linier berganda diperoleh hasil sebagai berikut:

1. Uji validitas dan uji Reliabilitas menunjukkan bahwa semua item pertanyaan dari pelatihan dan pengembangan sumber daya manusia $\left(\mathrm{X}_{2}\right)$ dan prestasi kerja karyawan $(\mathrm{Y})$ diterima atau semua pertanyaan yang diajukan kepada responden adalah valid dan reliable.

2. Uji $t$ hitung didapat nilai $t$ hitungpelatihan $14.053>t_{\text {tabel }} 1.65993$ dan $.000<\quad 0.05$ dan nilai $t$ hitungpengembangan sumber daya manusia $14.053>t_{\text {tabel }} 1.65993$ dan $.000<0.05$ sehingga hipotesis yang menyatakan pelatihan dan pengembangan sumber daya manusia berpengaruh positif secara parsial terhadap Prestasi Kerja Karyawan pada PT. Jembo Energindo.

3. Uji $F$, didapat $F$ hitung $>F$ tabel atau $268.793>3.09$ atau tingkat signifikasi (sig) $0.000<0.05$ sehingga hipotesis yang menyatakan pelatihan dan pengembangan sumber daya manusia secara bersama-sama berpengaruh terhadap prestasi kerja karyawan pada PT. Jembo Energindo

4.Berdasarkan hasil koefisien determinasi menunjukkan bahwa pelatihan dan pengembangan sumber daya manusia memberikan sumbangan sebesar 84,2\% terhadap Prestasi Kerja Karyawan pada PT. Jembo Energindo.

\section{Saran}

1. Diharapkan PT JemboEnergindomenjadipabrikan yang maju dan bijak dalam membuat danmenentukan Pelatihan dan menentukan cara untuk mengembangkan karyawan sehingga terciptanya Prestasi Kerja bahkan meningkatnya Prestasi Kerja yang luar biasa.

Hendaknyaperusahaandapatmemberika nPelatihan yang tepat dan memberikan peluang kesempatan yang lebih besar bagi para karyawan untuk mengembangkan diri supaya dapat bersaing secara sehat, membanggakan perusahaan dant entunyamemberikanumpan balik kepada perusahaan berupa Prestasi Kerja yangluarbiasa.

2. Prestasi kerja karyawan PT Jembo Energindo perlu dikembangkan lagi dengan dilakukan pelatihan dan pengembangan sumber daya manusia yang berkesimbungan, hal ini guna meningkatkan kemampuan karyawan dalam bekerja nanti

\section{DAFTAR PUSTAKA}

Sedarmayanti. 2017. Perencanaandan Pengem bangan Sumber Daya Manusia. Bandung: PT Refika Aditama. 
Priansa, Donni Juni. 2016. Perencanaan \& Pengembangan SDM. Bandung: Alfabeta.

Dessler, Gary. 2015.Manajemen Sumber Daya Manusia. Jakarta: Salemba Empat.

Radhatullah, S. \&Jauhar, M. 2015.Pengantar

Jakarta:Prestasi Manajemen, Pustakarya.

Sutrisno, Edy. 2016. Manajemen Sumber Daya Manusia. Jakarta: Fajar Interpratama Mandiri.

Mangkunegara, Anwar Prabu. 2013. Manajemen Sumber Daya Manusia. Bandung: PT Remaja

Rosdakarya.

Mangkunegara, Anwar Prabu 2015.Manajemen Sumber Daya Manusia. Bandung: PT Remaja

Rosdakarya.

Kasmir.2016.Manajemen Sumber Daya Manusia Teori dan Praktek. Jakarta: Rajawali Pers.

Flippo. 2015. Perencanaan \& Pengembangan Sumber Daya Manusia. Cetakan Kelima.Jakarta:

RinekaCipta.

Suparyadi, H. 2015. Manajemen Sumber Daya Manusia. Yogyakarta: CV Andy Offset, Edisi 1.

Mutiara Sibarani Panggabean. 2016. Manajemen Sumber Daya Manusia. Tangerang Selatan: Universitas Terbuka.
Sinambela, L. P. 2016. Manajemen Sumber Daya Manusia. Jakarta: Sinar Grafika Offset.

Riady, Edi. 2015. Metode dan Instrumen Penelitian Ekonomi dan Bisnis. Tangerang: Pustaka Mandiri.

Wiratna, V, Sujarweni.2015.Metodologi Bisnisdan Ekonomi.Yogyakarta: PustakaBaru Press.

Sugiyono. 2017. Metode Penelitian Bisnis. Bandung: Alfabeta.

Sugiyono.

2018.MetodePenelitianManajemen.

Bandung: Alfabeta.

Basuki, A. T. \&Prawoto, N. 2016.AnalisisRegresiDalamPenelitianEk onomi\& Bisnis.Depok: PT RajafrafindoPersada.

Priyastama, R. 2017. BukuSaktiKuasai SPSS Pengolahan Data \&Analisis Data, Yogyakarta : Start Up 